\title{
Nonketotic Hyperglycinemia: Two Patients with Primary Defects of P-Protein and T-Protein, Respectively, in the Glycine Cleavage System
}

\author{
KIYOSHI HAYASAKA, KEIYA TADA, ${ }^{(22)}$ GORO KIKUCHI, SUSAN WINTER, AND \\ WILLIAM L. NYHAN \\ Departments of Pediatrics and Biochemistry, Tohoku University School of Medicine, Sendai, Japan 980 [K.H. \\ K.T., G.K.]; Department of Genetics, Valley Children's Hospital, Fresno, California [S.W.J; Department of \\ Pediatrics, University of California, San Diego, La Jolla, California, USA [W.L.N.]
}

\section{Summary}

The glycine cleavage system was investigated in the livers and brains of two patients with typical nonketotic hyperglycinemia who died in the neonatal period. The overall activity of the glycine cleavage system was found to be extremely low in both the liver and brain of each patient. In one patient, the disturbance of the glycine cleavage system was due to absence of activity of the $P$ protein. Immunochemical analysis indicated that this resulted from an absence of the enzyme protein. In the other patient, the activity of the $\mathrm{T}$-protein was undetectable in the brain and was extremely low in the liver. Clinically classic nonketotic hyperglycinemia resulted from molecular defects in two different protein components of the glycine cleavage system.

The glycine cleavage system is the major pathway for the catabolism of glycine in vertebrates $(5,17)$. The enzyme system (Fig. 1), which is confined to the mitochondria, is composed of four protein components: P-protein (a pyridoxal phosphatedependent glycine decarboxylase), H-protein (a lipoic acid-containing protein), T-protein (a tetrahydrofolate-requiring enzyme), and L-protein (a lipoamide dehydrogenase) $(7,8)$. The glycine cleavage reaction is reversible.

Hyperglycinemia is associated with decreased catabolism of glycine caused by reduction in the activity of the glycine cleavage system $(16,18)$. Patients with hyperglycinemia have been classified as belonging to two types: ketotic and nonketotic. Ketotic hyperglycinemia is a syndrome that accompanies a number of disorders in which organic acidemia results from the deficiency of enzymes involved in the metabolism of branched chain amino acids (13). In nonketotic hyperglycinemia there is no accumulation of organic acids in body fluids (15). In 1981, Hiraga et al. (4), investigated the molecular nature of the glycine cleavage system in the liver and brain of a patient with nonketotic hyperglycinemia, in whom the clinical picture was that of a progressive neurodegenerative disorder quite different from the typical form of nonketotic hyperglycinemia. Low activities were found for P-protein and H-protein, and there was a structural abnormality of $\mathrm{H}$-protein, making it devoid of lipoic acid. We conclude that the primary lesion in the patient was in a structural abnormality of $\mathrm{H}$-protein. We recently had the opportunity to investigate the glycine cleavage system in the liver and brain obtained at autopsy from two patients with the typical form of nonketotic hyperglycinemia. Molecular defects were established in both, in one in the P-protein and in the other in the T-protein.

\section{CASE REPORTS}

Patient 1. J.L. (19) was admitted to the Pediatric Intensive Care Unit of Valley Children's Hospital in Fresno, California, on the 3rd day of life with marked hypotonia, intermittent apnea, and poor responsiveness to stimuli. He was born to a 26-yearold GII PI AO healthy mother and a 27 -year-old healthy father at 42 wk gestation. Pregnancy was uneventful and delivery was normal, vertex. Birth weight was $3891 \mathrm{~g}$. Family history was negative for similar problems and there was no consanguinity.

Apgar scores were 9 at both 1 and $5 \mathrm{~min}$. The infant was lethargic and had a poor suck from birth; these symptoms gradually worsened until the time of admission. On admission, the weight was $3695 \mathrm{~g}$, head circumference $35 \mathrm{~cm}$, temperature $96.2^{\circ} \mathrm{F}$., pulse $112 / \mathrm{min}$, and respiratory rate $50 / \mathrm{min}$. Periodic breathing was present with intermittent apnea requiring intubation and ventilatory support. The pupils were constricted but reactive. The child was hypotonic, nearly areflexic, and there was minimal response to painful stimuli. The liver was palpable at $1 \mathrm{~cm}$. The suck, grasp, and Moro reflexes were poor. Sepsis was suspected and treatment with antibiotics was begun; cultures were negative. Complete blood count, electrolytes, calcium, glucose, serum glutamic oxaloacetic transaminase, and urinalysis were normal. No ketones were detected in the urine. The blood concentration of ammonia was $64 \mu \mathrm{mole} / \mathrm{liter}$ (normal, 11-35). $\mathrm{pH}$ was $7.30, \mathrm{PCO}_{2}$ was $49, \mathrm{PO}_{2}$ was 56 , and bicarbonate $23 \mathrm{mEq} /$ liter. An EEG showed a burst suppression pattern. Urinary amino acid screen showed an elevated amount of glycine. The concentration of glycine in plasma was $2250 \mu \mathrm{mole} /$ liter and in cerebrospinal fluid $337 \mu$ mole/liter. These data led to a diagnosis of nonketotic hyperglycinemia.

At the request of the parents ventilator support was withdrawn, and the infant died on the 12th day of life. Autopsy revealed a subarachnoid hemorrhage of the spinal cord, spinal cord hydromyelia, and agenesis of the corpus callosum.

Patient 2. B.M. (19) was admitted to the Newborn Intensive Care Unit of the Children's Hospital of San Francisco on the 3rd day of life because of lethargy, bordering on coma. He had been born at term to a young, healthy primigravida after a normal pregnancy, labor, and delivery. Apgar score was 9 . Birth weight was $3280 \mathrm{~g}$. He appeared well at birth and nursed well the first day, but became lethargic on the second day and began to feed poorly. On admission the weight was $3210 \mathrm{~g}$. He was very lethargic, and he had minimal suck, poor tone and Moro, and decreased deep tendon reflexes. Physical examination was otherwise unrevealing. Antibiotic therapy was started but his condition worsened and cultures were negative. A complete blood count and platelet count were normal. The $\mathrm{pH}$ was 7.42 and the blood gases and electrolytes were normal. The concentration of ammonia was $66 \mu$ mole/liter. By day 4 coma was deep and he developed periods of apnea; he required intubation and a ventilator on day 5 .

High voltage electrophoresis of the urine revealed a gross 


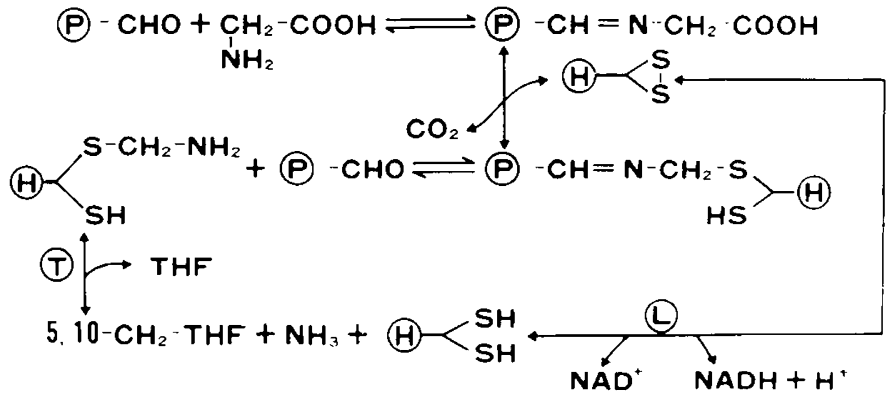

Fig. 1. The glycine cleavage system. The circled P, H, L, and T represent the four protein components of the system.

elevation of the concentration of glycine. Quantitative analysis gave a value of $604 \mu$ mole of glycine per mg creatinine. The concentration of glycine in the plasma was $121 \mu \mathrm{mole} / \mathrm{liter}$. The concentration of glycine in the cerebrospinal fluid was determined on two occasions; the values were 25 and $28 \mu$ mole/liter. The respective cerebral spinal fluid to plasma ratios were 0.21 and 0.39 .

Seven exchange transfusions lowered the plasma concentration of glycine as low as $73 \mu$ mole/liter, but his coma did not improve. Similarly, treatment with sodium benzoate and strychnine were without defect. Ventilator support was discontinued on the 20 th day of life and the infant died.

\section{MATERIALS AND METHODS}

Chemicals. $\left[{ }^{14} \mathrm{C}\right]$ Bicarbonate and $\left[1-{ }^{14} \mathrm{C}\right]$ glycine were purchased from New England Nuclear, Boston; $\mathrm{NAD}^{+}$, NADH, dithiothreitol, lipoamide, and D,L-tetrahydrofolate from Sigma Chemical Company, St. Louis; pyridoxal phosphate from Kyowa Hakko-Kogyo, Tokyo; and leupeptin (a microbial protease inhibitor) from the Peptide Institute, Osaka.

Methylene tetrahydrofolate was prepared chemically from tetrahydrofolate and formaldehyde (11).

Preparation of homogenates and sonic extracts of tissues. The specimens of the liver and brain were obtained at autopsy from patient 1 within $0.5 \mathrm{~h}$ and patient 2 within $24 \mathrm{~h}$ after death and immediately stored at $-80^{\circ} \mathrm{C}$ until analyzed. Control samples of livers and brains were obtained at autopsy from a 5-year-old female who died of congenital heart disease (Control 1), from a 55-year-old male who died of pulmonary edema (Control 2 ), and from a 38-year-old male who died of idiopathic hypertrophic subaortic stenosis (Control 3). These specimens were also frozen within 2-6 h after death and stored until studied. Frozen tissues were thawed and homogenized with 4 volumes of $20 \mathrm{mM}$ potassium phosphate buffer ( $\mathrm{pH} 7.0$ ) containing $1 \mathrm{mM}$ dithiothreitol, $1 \mathrm{mM}$ pyridoxal phosphate, and $10 \mu \mathrm{g} / \mathrm{ml}$ leupeptin. The homogenates were passed through four layers of gauze and used for the assay of the activities of the glycine cleavage system and lipoamide dehydrogenase. For the assay of the activities of Pprotein $\mathrm{H}$-protein and $\mathrm{T}$-protein, the homogenates were subjected to sonic treatment at $140 \mathrm{~W}$ for $5 \mathrm{~min}$ and centrifuged at $105,000 \times g$ for $50 \mathrm{~min}$ and the supernatant fluids were used after gel filtration on Sephadex G-25. For the assay of H-protein activity, the supernatant fluids, after centrifugation, were dialyzed overnight against $20 \mathrm{mM}$ potassium phosphate buffer $(\mathrm{pH}$ 7.0) and subjected to heat treatment at $100^{\circ} \mathrm{C}$ for $1 \mathrm{~min}(9)$.

$P$-protein and H-protein from chicken liver. These proteins were purified from chicken liver mitochondria by the method of Hiraga and Kikuchi (3).

Preparation of antibody against chicken liver P-protein. P. protein purified to homogeneity from chicken liver mitochondria was used to immunize white rabbits using the standard procedure (1). Antisera were collected and purified as IgG as described previously (4). The antibody against chicken liver P-protein reacted with $\mathrm{P}$-protein of human liver in a manner similar to the P-protein of chicken liver.
Assay of enzyme activities. The activity of the glycine cleavage reaction was determined essentially by the method of Sato et al. (13). The reaction mixture contained, in a final volume of $1 \mathrm{ml}$, $100 \mu$ mole of potassium phosphate buffer ( $\mathrm{pH} 7.4$ ), $0.4 \mu$ mole of pyridoxal phosphate, $1 \mu$ mole of $\mathrm{NAD}^{+}, 1 \mu$ mole of $\mathrm{D}, \mathrm{L}-$ tetrahydrofolate, $10 \mu$ mole of $\left[1-{ }^{14} \mathrm{C}\right]$ glycine (specific activity, $0.05 \mathrm{Ci} / \mathrm{mole}$ ), and homogenate. The reaction was initiated by the addition of the labeled substrate and carried out for $20 \mathrm{~min}$ at $37^{\circ} \mathrm{C}$ in a Warburg-type flask. The reaction was terminated by the addition of $0.1 \mathrm{ml}$ of $50 \%$ trichloroacetic acid, and the $\left[{ }^{14} \mathrm{CO}_{2}\right]$ produced was measured as described previously (6).

Activities of P-protein and $\mathrm{H}$-protein were assayed by the glycine- $\left[{ }^{14} \mathrm{CO}_{2}\right]$ exchange reaction according to the method of Motokawa and Kikuchi (9) except that the final volume was 0.5 $\mathrm{ml}$. For the assay of P-protein activity, the assay mixture was supplemented with $50 \mu \mathrm{g}$ of chicken liver H-protein, and for the assay of $\mathrm{H}$-protein activity, with $8 \mu \mathrm{g}$ of chicken liver P-protein. Glycine was omitted in the control systems.

Activity of T-protein was determined by measuring glycine cleavage activity in the reaction system supplemented with 32 $\mu \mathrm{g}$ of chicken liver P-protein and $48 \mu \mathrm{g}$ of chicken liver $\mathrm{H}$ protein. In the control assay, boiled enzyme solution was used. The activity of $T$-protein was also assayed by measuring the synthesis of glycine from methylene-tetrahydrofolate, $\mathrm{NH}_{4} \mathrm{Cl}$ and $\left[{ }^{14} \mathrm{C}\right]$ bicarbonate in the reaction system supplemented with chicken liver P-protein and chicken liver H-protein, essentially according to the method of Okamura-Ikeda et al. (10). The reaction mixture contained, in a final volume of $0.5 \mathrm{ml}, 25$ $\mu$ mole of Tris- $\mathrm{HCl}$ buffer ( $\mathrm{pH} 8.0$ ), $0.75 \mu$ mole of D,L-methylenetetrahydrofolate, $5 \mu$ mole of $\mathrm{NH}_{4} \mathrm{Cl}, 10 \mu$ mole of $\left[{ }^{14} \mathrm{C}\right]$ bicarbonate $(0.1 \mathrm{Ci} / \mathrm{mole}), 0.125 \mu$ mole of pyridoxal phosphate, $5 \mu$ mole of dithiothreitol, $16 \mu \mathrm{g}$ of chicken liver P-protein, $60 \mu \mathrm{g}$ of chicken liver $\mathrm{H}$-protein, $20 \mu \mathrm{g}$ of diaphorase, and the enzyme preparation. In the control assay $\mathrm{D}, \mathrm{L}$-methylene-tetrahydrofolate was omitted. The reaction was carried out for $30 \mathrm{~min}$ at $37^{\circ} \mathrm{C}$ and the radioactivity of the $\left[{ }^{14} \mathrm{C}\right]$ glycine formed was determined as described (6).

The activity of lipoamide dehydrogenase was determined spectrophotometrically by measuring the lipoamide-dependent oxidation of NADH as described previously (4).

\section{RESULTS}

Activities of the glycine cleavage system and its individual components. The overall activities of the glycine cleavage system in the livers of the patients with nonketotic hyperglycinemia were found to be extremely low (Table 1). The level of activity in the liver of each patient was similar and approximately $7 \%$ of the control mean. The activities in the brains were even lower than in liver and were also lower than those of controls.

Examination of the activities of the individual components revealed that in the liver and brain of patient 1 , the activity of the P-protein was undetectable (Table 1). The activities of the other components and of lipoamide dehydrogenase (Table 2) were not significantly different from those of controls.

In patient 2 , the activity of $T$-protein was not detected in the brain and was extremely low in the liver. The activity detected in the liver was $0.1-0.2 \%$ of those of controls when assayed by means of the glycine cleavage reaction and was $4-7 \%$ of those of controls when assayed by the glycine synthesis reaction. The activity of the other components of the glycine cleavage system in patient 2 did not differ significantly from those of controls (Table 1 and 2).

Immunochemical analysis of $P$-protein in the liver of patient 1 . To investigate whether the lack of detectable activity of P-protein in patient 1 was a consequence of absence of the enzyme protein, immunotitration and Ouchterlony double diffusion analysis of P-protein were carried out using antibody prepared against purified chicken liver P-protein. Extracts of control livers gave single precipitin bands in Ouchterlony double diffusion analysis, but the liver extract of the patient 1 did not show any precipitin 
Table 1. Activities of the glycine cleavage system and its individual enzyme components in the liver and brain of two patients with nonketotic hyperclycinemia ${ }^{1}$

\begin{tabular}{cccccc}
\hline & \multicolumn{5}{c}{ Activity $(\mu$ mole of product/g protein $/ \mathrm{h})$} \\
\cline { 2 - 6 } $\begin{array}{c}\text { Source of } \\
\text { tissue }\end{array}$ & $\begin{array}{c}\text { Glycine } \\
\text { cleavage }\end{array}$ & P-protein & H-protein & T-protein \\
\hline Liver & & & & & \\
Patient 1 & 0.3 & 0 & 16.1 & $72.2^{2}$ & $7.3^{3}$ \\
Patient 2 & 0.4 & 7.4 & 16.2 & $0.1^{2}$ & $0.3^{3}$ \\
Control 1 & 5.2 & 5.7 & 18.3 & $77.9^{2}$ & $7.7^{3}$ \\
Control 2 & 4.4 & 4.8 & 15.3 & $66.2^{2}$ & $7.0^{3}$ \\
Control 3 & 3.8 & 4.5 & 14.6 & $52.1^{2}$ & $7.3^{3}$ \\
Brain & & & & & \\
Patient 1 & 0.2 & 0 & 3.2 & 1.4 & \\
Patient 2 & 0.1 & 0.6 & 4.2 & 0 & \\
Control 1 & 0.6 & 0.3 & 3.2 & 4.0 & \\
Control 2 & 0.9 & 0.2 & 6.1 & 3.4 & \\
Control 3 & 0.5 & 0.2 & 3.9 & 2.1 & \\
\hline
\end{tabular}

${ }^{1}$ Glycine cleavage activity was assayed using $20 \%$ homogenates $(5-12$ mg protein), and the activities of P-protein, $\mathrm{H}$-protein, and T-protein were assayed using sonicated homogenates (2-7 mg protein). P-protein was assayed in the presence of $50 \mu \mathrm{g}$ of purified chicken liver $\mathrm{H}$-protein, and $\mathrm{H}$-protein was assayed in the presence of $8 \mu \mathrm{g}$ of purified chicken liver P-protein.

${ }^{2}$ The activity of T-protein was determined by the glycine cleavage activity in a reaction system supplemented with $32 \mu \mathrm{g}$ of chicken liver P-protein and $48 \mu \mathrm{g}$ of chicken liver H-protein.

${ }^{3}$ The activity of T-protein was also determined by synthesis of glycine in a reaction system supplemented with $16 \mu \mathrm{g}$ of chicken liver P-protein, $60 \mu \mathrm{g}$ of chicken liver H-protein, and $20 \mu \mathrm{g}$ of diaphorase.

Table 2. Activity of lipoamide dehydrogenase in livers of patients and controls ${ }^{1}$

\begin{tabular}{cc}
$\begin{array}{c}\text { Source of } \\
\text { tissue }\end{array}$ & $\begin{array}{c}\text { Activity } \\
(\mu \text { mole/g protein } / \mathrm{min})\end{array}$ \\
\hline Patient 1 & 69.8 \\
Patient 2 & 59.1 \\
Control 1 & 78.8 \\
Control 2 & 64.6 \\
Control 3 & 62.8 \\
\hline
\end{tabular}

${ }^{1} 0.2-0.4 \mathrm{mg}$ of liver homogenates was used for the assay.

band. The result of the immunotitration experiments which were carried out using the liver extract from a control and the mixture of the liver extracts from control and patient 1 are shown in Figure 2. The slopes of the immunotitration line obtained for both of the extracts were quite parallel. These results indicate that the liver extract of patient 1 does not contain protein that is reactive with the antibody against $\mathrm{P}$-protein, and indicate that the absence of P-protein activity in patient 1 represents an absence of the enzyme protein.

\section{DISCUSSION}

The present study has clearly indicated a fundamental defect in the glycine cleavage system in the brains and livers of each of the two patients with the typical form of nonketotic hyperglycemia. In one of the patients, the abnormality of the glycine cleavage system was found to be due to the absence of the activity of the P-protein. An absence of immunoreactive P-protein was consistent with an absence of the enzyme protein itself. We conclude that the defect in the P-protein is the primary lesion in patient 1 .

A reduction in the activity of $\mathrm{P}$-protein in liver and brain was reported in a patient with an atypical form of nonketotic hyperglycinemia in whom an anomaly in the $\mathrm{H}$-protein which was devoid of lipoic acid appeared to represent the primary lesion

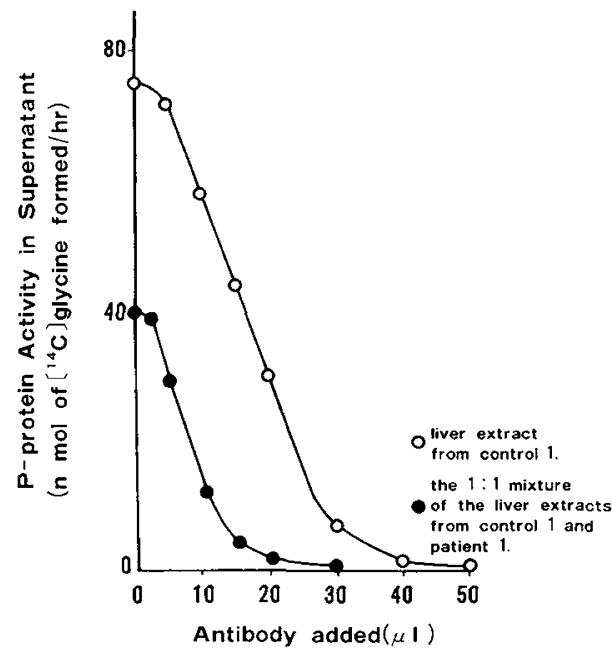

Fig. 2. Immunotitration of P-protein of liver extract from control 1 and the 1:1 mixture of the liver extracts of control 1 and patient 1 . Liver extracts were prepared from the same amounts of liver homogenates of control 1 and patient 1 as described in "Materials and Methods." Increasing amounts of anti-P-protein IgG were added to the fixed amount of the respective samples. The mixtures were incubated at $37^{\circ} \mathrm{C}$ for $20 \mathrm{~min}$, then left at $0^{\circ} \mathrm{C}$ for $30 \mathrm{~min}$. The supernatant fluids obtained after centrifugation were assayed for P-protein activity. $(\mathrm{O}-\mathrm{O})$ liver extract from control 1 and $(\longrightarrow$ ) mixture of liver extracts from control 1 and the patient 1 .

(4). A decrease in the activity of P-protein was also observed in the liver of rats treated with dipropylacetic acid $(2,6)$, but these reductions in the activity of P-protein appeared to be due not to a decrease in the actual amount of the enzyme protein but to a partial inactivation of the P-protein in which the protein is so modified as to lose enzyme activity.

In patient 2 the activity of the T-protein was undetectable in the brain and was extremely low in the liver. This defect in $T$ protein appeared to be the primary molecular defect in this patient. Recently, Okamura-Ikeda et al. (10), reported that Tprotein, purified to apparent homogeneity from chicken liver mitochondria, is a monomer with a molecular weight of 38,000 by gel filtration. The enzyme requires tetrahydrofolate as a cofactor. Antibody against T-protein is not yet available; therefore, it is not possible to determine whether the observed reduction in the activity of T-protein is due to a decrease in the actual amount of the enzyme protein or an alteration in structure that interferes with enzyme activity.

Our data indicate that the typical phenotype of nonketotic hyperglycinemia is caused by a primary disturbance in the glycine cleavage system. This may result from a genetically determined defect in any one of the components of this complex enzyme system. This may be similar to the situation that observed in the disorder of pyruvate dehydrogenase enzyme complex which is composed of at least three individual enzyme components, and separate individual patients with defects in at least two of the enzyme components have been described (12). The occurrence of a structural defect, an absent corpus callosum, in the brain of patient 1 may or may not be related to the metabolic abnormality. We have encountered one patient with a similar anatomic abnormality in whom there was deficiency of the pyruvate dehydrogenase complex.

The data obtained indicate also that the individual enzymes of the glycine cleavage system in the brain and in the liver are the same proteins. Synthesis of any individual enzyme protein in either organ may be controlled by the same gene.

\section{REFERENCES AND NOTES}

1. Chase, M. S.: Production of antiserum. In: C. A. Williams, M. W. Chase: Methods in Immunology and Immunochemistry, Vol. 1, pp. 197-254, (Academic Press, Inc., New York, 1967). 
2. Hayasaka, K., Kochi, H., Hiraga, K. and Kikuchi, G.: Occurrence of a catalytically less active glycine decarboxylase in the liver of rat treated with dipropylacetic acid. Biochem. Internatl., 3: 51 (1981).

3. Hiraga, K. and Kikuchi, G.: The mitochondrial glycine cleavage system: Purification and properties of glycine decarboxylase from chicken liver mitochondria. J. Biol. Chem., 225: 11664 (1980).

4. Hiraga, K., Kochi, H., Hayasaka, K., Kikuchi, G., and Nylan, W. L.: Defective glycine cleavage system in nonketotic hyperglycinemia: occurrence of a less active glycine decarboxylase and an abnormal aminomethyl carrier protein. J. Clin. Invest., 68: 525 (1981).

5. Kikuchi, G.: The glycine cleavage system: Composition, reaction mechanism, and physiologic significance. Mol. Cell. Biochem., l: 169 (1973).

6. Kochi, H., Hayasaka, K. Hiraga, K., and Kikuchi, G.: Reduction of the level of the glycine cleavage system in the rat liver resulting from administration of dipropylacetic acid. An experimental approach to hyperglycinemia. Arch. Biochem. Biophys., 198: 589 (1979).

7. Kochi, H, and Kikuchi, G.: Mechanism of reversible glycine cleavage reaction in Arthrobacter globiformis. Function of lipoic acid in the cleavage and synthesis of glycine. Arch. Biochem. Biophys., 713: 71 (1976).

8. Motokawa, T. and Kikuchi G.: Glycine metabolism by rat liver mitchondria. Reconstitution of the reversible glycine cleavage system with partially purified protein components. Arch. Biochem. Biophys., 164: 624 (1974).

9. Motokawa, T. and Kikuchi, G.: Glycine metabolism by rat liver metochondria. IV. Isolation and characterization of hydrogen carrier protein, as essential factor for glycine metabolism. Arch. Biochem. Biophys., 135: 401 (1969).

10. Okamura-Ikeda, K., Fujiwara, K., and Motokawa, Y.: Purification and characterization of chicken liver T-protein, a component of the glycine cleavage system. J. Biol. Chem., 257: 135 (1982).

11. Osborn, M. J., Talbert, P. T., and Huennekens, F. M.: The structure of "active formaldehyde" ( $\mathrm{N}^{5}, \mathrm{~N}^{10}$-methylene tetrahydrofolic acid). J. Am. Chem. Soc., 82: 4921 (1960).

12. Robinson. B. H., Taylor, J., and Sherwood, W. G.: The genetic heterogeneity of lactic acidosis: Occurrence of recognizable inborn errors of metabolism in a pediatric population with lactic acidosis. Pediatr. Res., 14: 956 (1980)

13. Rosenberg, L. E.: Disorders of propionate, methylmalonate, and cobalamine metabolism. In: J. B. Stanbury, J. B. Wyngaarden, and D. S. Fredrickson: The Metabolic Basis of Inherited Disease, pp. 411-429, (McGraw-Hill Book Co., New York, 1978)

14. Sato, $T$ Kochi, $H$ Sato, $N$, and Kikuchi, G. Glycine metabolism by rat liver mitochondria. III. The glycine cleavage and the exchange of carboxyl carbon of glycine with bicarbonate. J. Biochem., 65: 77 (1969)

15. Tada, K., Corbeel, L. M., Eeckels, R., and Eggermont, E.: A block in glycine cleavage reaction as a common mechanism in ketotic and nonketotic hyperglycinemia. Pediatr. Res., 8: 721 (1974).

16. Tada, K., Narisawa, K., Yoshida, T., Konno, T., Yokoyama, K., Nakagawa, H., Tanno, K., Mochizuki, K., Arakawa, T., Yoshida, T., and Kikuchi, G.: Hyperglycinemia: A defect in glycine cleavage reaction. Tohoku J. Exp. Med., 98: 289 (1969).

17. Yoshida, $T$. and Kikuchi, G.: Comparative study on major pathways of glycine and serine catabolism in vertebrate livers. J. Biochem., 72: 1503 (1972)

18. Yoshida, T., Kikuchi, G., Tada, K., Narisawa, K. and Arakawa, T.: Physiological significance of glycine cleavage system in human liver as revealed by the study of a case of hyperglycinemia. Biochem. Bipohys. Res. Commun., 35 . 577 (1969).

19. The authors wish to acknowledge the assistance of Drs. S. Cederbaum, K. Rajani, J. Brunberg and H. Sherman who directed the clinical management of patient 1 and referred him to us for further studies; and of Dr. Toshiko Hirata who directed the clinical management of patient 2 and referred him to us for the original diagnosis.

20. Informed consent was obtained for the families of all subjects in this study.

21. This research was supported in part by grants from the Ministry of Education, Science and Culture and from the Ministry of Health and Welfare of Japan.

22. Requests for reprints should be addressed to: Dr. K. Tada, Department of Pediatrics, Tohoku University School of Medicine, Sendai 980, Japan.

23. Received for publication November 4, 1982.

24. Accepted for publication March 30, 1983.

\title{
Acute Hyperammonemia in the Young Primate: Physiologic and Neuropathologic Correlates
}

\author{
THERESA M. VOORHIES, MICHELLE E. EHRLICH, THOMAS E. DUFFY ${ }^{(46)}$ CAROL K. PETITO, \\ AND FRED PLUM
}

Departments of Neurology [T.M.V., M.E.E., T.E.D., F.P.] and Pathology (Neuropathology) [C.K.P.], Cornell University Medical College, New York, New York, USA

\begin{abstract}
Summary
Infusion-induced acute ( $\leq 24 \mathrm{~h}$ ) hyperammonemia to concentrations up to five times normal $(0.19 \pm 0.03$ versus $0.90 \pm 0.08$ $\mathrm{mM}$ ) was studied in eleven 6-9-month-old Macaca mullata. The young primates developed a progressive reduction of consciousness that correlated in severity directly with the elevation of blood ammonia concentration. Hyperventilation, electroencephalographic slowing, occasional seizure activity, and, eventually, apneustic breathing also occurred. Intracranial pressure rose from $76 \pm 7$ to $167 \pm 12 \mathrm{mmH}_{2} \mathrm{O}$. Arterial oxygen and blood pressure remained within normal limits. Neuropathologic examination showed early astrocytic changes, consisting primarily of swollen perikaryal cytoplasm and processes, and membranous whorls. The absence of neuronal pathology suggests that the acute, limited insult, as occurs in many of the childhood hyperammonemic syndromes, is fully reversible.
\end{abstract}

\section{Abbreviations}

EEG, electroencephalogram

FAM, formaldehyde, glacial acetic acid, and absolute methanol (1:1:8)

ICP, intracranial pressure

RER, rough endoplasmic reticulum

Hyperammonemia of infancy and childhood may occur in many settings: Reye's syndrome $(18,23,39)$, hereditary deficiencies of urea cycle enzymes $(10,20)$, prematurity $(5,6,15)$, birth asphyxia (19), and as a complication of urinary tract infections (38), valproic acid therapy (14), asparaginase therapy (30), and intravenous alimentation with amino acids or protein hydrolysates $(21,24)$. These illnesses share a common clinical picture, suggesting that hyperammonemia produces a specific constellation of signs and symptoms in infants and children, as in adults. 